\title{
The Factors Affecting Human Understanding of the Perceived World in the Novel "Room" by Emma Donoghue: An Analysis of the Lead Character
}

\author{
Nirwana Nirwana and Nurul Khaswar \\ Alauddin State Islamic University of Makassar, Makassar, Indonesia \\ nirwana.nirwana@uin-alauddin.ac.id
}

\section{ARTICLE HISTORY \\ Received : 26 July 2020 \\ Revised : 27 August 2020 \\ Accepted : 27 September 2020}

\section{KEYWORDS}

Human Understanding

Perceived World

Novel "Room"

John Locke

\begin{abstract}
This study is intended to describe the factors affecting human understanding of the perceived world based on John Locke's theory by analysing the lead character of Emma Donoghue's novel Room . Locke divided the way people gaining human understanding of knowledge through experience in two ways which are from sensory experience and inner experience. By using qualitative approach this study extracted Jack's experience and categorise in to sensory experience and inner experience which is related to his understanding of the perceived world. Between the sensory and the inner experience, they connected with each other, the experience gained from the eyes will be remembered by the inner experience, and what is smelled by the nose will be remembered by the inner experience. From sensory and inner experience, they produce knowledge and knowledge influence their perception. Every person has a different experience from their respective sensory and their experience affecting perception.
\end{abstract}

\section{Introduction}

Basically, the babies were born without knowledge or commonly called tabula rasa. They fill their knowledge little by little through experience, sensory perceptions of the world around them. Locke (1932) says that humans were born without innate experience from their parents. A baby was born with a blank paper, known as tabula Rasa. Locke can be referred to empiricism which is flowing or understanding that argues that all human skill and knowledge arise from empiric experience that enters through the sense organs. According to Rakhmat (2005), an experience of objects, events, or relationships obtained by deducing information and interpreting messages is a perception. Meanwhile, according to Bimo (2003), perception is something that shows the activity of feeling, interpreting and understanding objects, both physical and social.

Locke's thesis contained in his book, "An Essay Concerning Human Understanding", which he issued when he opposed the teachings of innate ideas to rationalist people. The mind, when a person is born, is empty, like a white paper or tabula rasa, which has no writing on it. Every idea that he gets must come through experience, what is meant by experience here is a sensory experience or that knowledge comes from the observations that we make of our own minds with tools that Locke calls inner sense. Our hearing or vision takes precedence a truly appropriate rule because modern medicine proves that the sense of hearing functions before the sense of sight. He began to grow in a baby in the first few weeks. While the new sense of sight began in the third month and became perfect stepping in the sixth month. As for the ability of the mind and eyes of the heart that function far after the two senses above. Thus it can be said that the sequence of the mention of the senses in the above verse reflects the stage of development of these sensory functions. Then the plural form is chosen for vision and heart, because what is heard is always the same as both someone and the sound comes. This is different from what is seen, the posit of the footing and the direction of view given birth to a difference, as well as the work of mind and heart.

As a Muslim, in Al-Quran there is a verse which explains how a baby is born without knowledge, hearing, sight, and heart so that we are all grateful:

"And Allah has extracted you from the wombs of your mother not knowing a thing. And He made for you hearing and vision and intellect that perhaps you would be grateful." Q.S An-Nahl: 78.

According to Shihab (2002: 302-304), Sayyid Qutb makes this verse simple that is a presentation in human life that cannot be reached by birth. When he expels you from your mother while you are not tangible. He can bring you out of the bowels of the earth and bring you back to life. When he takes you out of your mothers, all of you in a state of not knowing anything that around you and he makes for your hearing, sight and various hearts, as supplies and tools to gain knowledge so that you are grateful by using tools in accordance with Allah's purpose to bestow it. 
A novel is a form of literary works that can be enjoyed by all the people. The types of the novel are divided in two, fiction and non-fiction then types of novels based on genre are romantic, horror, comedy and inspiration (Rahman, 2017). Nurgiyantoro (2010:10) suggests that the novel is a work offiction that is built by builder elements, i.e. elements of an intrinsic and extrinsic element. Novel as literary works can describe of human life in real terms. One of Donoghue's novel that illustrates the perspective of human understanding is Room (2010). As Jack experienced in the novel Room, the knowledge that he receives is limited into 11:11 room, Ma and Old Nick, TV, Story Books and weekly shopping. During his life, Jack has never seen the outside world and felt that the world in the Room is the real world thought that what is and he thinks out of the room is space. The knowledge received and experienced by Jack in the Room affects the different perceptions of the world while he is not out of the Room. So did Ma who lives seven years in Room.

The novel Room (2010) is written by Emma Donoghue, who is Iranian-Canadian. The novel is longlisted for the 2011 Orange Prize (Brown, 2011) and wins the 2011 Commonwealth Writers' Prize regional prize (Caribbean and Canada); is shortlisted for the Man Booker Prize in 2010 (Frenette, 2010) and is shortlisted for 2010 Rogers Writers' Trust Fiction Prize and the 2010 Goernor General's Awards(The Globe and Mail, 2010).

The novel does attract the attention of psychologists to investigate the story of a five-year-old child who is kept in a Room for his whole life. From another perspective we can see this novel as in Nugroho's 2010 thesis which examines "Ma's Trauma: Phsycholoanalytic Study on Emma Donoghue's Novel Room". He examines the factors that cause Ma to become one of the main characters in the novel Room and the characteristics after that trauma. He is using a psychoanalytic theory and using quantitative descriptive method. The second thesis is from Nurhayati \& Thoyibi (2017) whose title is "Novel Perspective in Emma Donoghue's Room (2010) Novel: A Sociological Approach". In her research, she uses the sociological approach and the researcher uses qualitative research to describe a child's through child perspective. According to the point of view shown by there, the researcher wants to experience from another perspective, from the standpoint of experience in human understanding of the perceived word.

In this study the researcher is interested in exploring human understanding of the perceived world from Jack's experience while he is kept in the room by using Lock's theory of Human understanding.

\section{Literature Review}

\subsection{Empiricism of John Locke (An Essay Concerning Human Understanding)}

This world from comes from the Greek work empeiriskos which comes from the word empeiria it means experience. According to Tafsir (2008), humans acquire knowledge through their experience and if it is returned to the Greek word the experience in question is sensory experience. Empiricism itself comes from Greek "Empirical" which means sensory experience. Therefore, empiricism is a notion that chooses experience as the main source of the introduction of both outward experiences concerning the world and inner experience (Nursafira et al., 2019), in this case concerning the human have brought about the nature of knowledge in themselves when they are born. According to Locke (1664) held that our ideas are either given in experience, or are complex ideas formed from simple ideas so given, but not that all our knowledge is based on experience. In Locke theory of human understanding the idea was received by sense in different ways and make a way processed in mind so they can be perceivable by human (Locke, 2004:84). He was adding, to have ideas before the mind is to be perceiving given or constructed sensory or quasi-sensory images things as perceived by sense. In Ibrahim (2017) Locke said that in order people to develop, they need to experience of what happened in their surround. Locke divided the way people gaining human understanding of knowledge through experience in two ways which are from sensory experience and inner experience.

\subsubsection{Sensory Experience}

Sensory knowledge is a kind of knowledge that is directly involved in producing knowledge by the organs of the body, using the five senses such as eye, ear, tough nose and hand. By sensory experience a person gained the knowledge and perception. Perception is the result from stimuli by sensory. This part of simple of sense such as division of simple ideas.

The way better to conceive the thoughts we get from circumstance it may not be wrong for us to consider them, in reference to the distinctive ways whereby they make their approaches to our minds, and make themselves distinguishable by us. To begin with, at that point, there are a few which come into our minds by one sense as it were. Fourthly, there are a few that make themselves way, and are proposed to the intellect by all the ways of sensation and reflection. We shall consider them apart under these several heads. Ideas of one sense. There are some ideas which have admittance only through one sense, which is peculiarly adapted to receive them. Thus light and colors, as white, red, yellow, blue with their several degrees or shades and mixtures, as green, scarlet, purple, sea-green, and the rest, come in only by the eyes. All kinds of noises, sounds, and tones, only by the ears. The several tasted and smells, by the nose and palate. And if these organs, or the nerves which are the conduits to convey them from without to their audience in the brain, the mind's presence-room are any of them so disordered as not to perform their functions, they have no postern to be admitted by no other way to bring themselves into view, and be perceived by the understanding. 


\subsubsection{Inner Experience}

Inner experience occurs when man has an awareness of own activities by remembering, desiring, believing, and etc (Hadiwijono, 2007:36). A person who has experienced something in his life will think for a better future life by learning from his experiences. Factors that influence of inner experience include:Simple ideas of reflection, Simple ideas are the operations of mind about its other ideas. The mind receiving the ideas mentioned in the foregoing chapter from without, when it turns it's view inward upon itself, and observes its own actions about those ideas it has, takes from thence other idea, which are as capable to be the objects of its contemplation as any of those it received from foreign things.

The idea of perception and the idea of willing have from reflection. The two great and principal actions of the mind, which are most frequently considered, and which are so frequent that every one that pleases may take notice of them in himself, are these two: perception, or thinking; and volition, or willing. The power of thinking is called the understanding, and the power of volition is called the will; and these two powers or abilities in the mind are denominated faculties. Of some of the modes of these simple ideas of reflection, such as are remembrance, discerning, reasoning, judging, knowledge, and fight, shall have occasion to speak here after.

Simple ideas of both sensation and reflection, including: a. ideas of pleasure and pain. There be other simple ideas which convey themselves into the mind by all the ways of sensation and reflection. Pleasure or delight, and its opposite, pain, or uneasiness; power; existence; unity's. mix with almost all our other ideas. Delight or uneasiness, one or other of them, join themselves to almost all our ideas both of sensation and reflection: and there is scarce any affection of our senses from without, any retired thought of our mind within, which I not able to produce in us pleasure or pain. By pleasure and pain, I would be understood to signify, whatsoever delights or molests us. Whether it arises from the thoughts of our minds, or anything operating on our bodies'. as motives of our actions. The infinite wise author of our being, having given us the power over several parts of our bodies, to move or keep them at rest as we think fit and also. By the motion of them, to move ourselves and other contiguous bodies, in which consist all the action of our body, having also given a power to our minds, in several instances, to choose, amongst its ideas, which it will think on, and to pursue the inquiry of this or that subject with consideration and attention, to cite us to these actions of thinking and motion that we are capable of, has been pleased to join to several thoughts, and several sensation as perception of delight.

\subsection{Synopsis}

The story starts on Jack 's fifth birthday. Jack is the only narrator of the story so we get to see the room through his eyes. For Jack, the room is the only real world. It consists of four walls, one wardrobe he sleeps in, a sink, a drawer, a bed, a television, a rug, a shelf with a couple of books and a rocker. Ma has been kidnapped during her college studies on the street seven years ago. After her son is born, she mobilizes all her strengths to offer Jack good life with as much structure and variety as possible. She creates an incredibly structured plan of their everyday routine so that Jack can feel happy and safe in the room. All Jack knows about their captor, Old Nick is that he comes at night, brings groceries, sleep with $\mathrm{Ma}$ and disappears the trash. He actually never sees him completely, only through the door in the wardrobe where he is supposed to sleep when Old Nick visits Ma. Though Ma does a lot for Jack, she knows it soon won't be enough.

Having learned about Old Nick's unemployment, she starts to worry about their lives and makes up an escape plan that requires Jack to be very brave. They start to rehearse for his escape and, at the same time, Ma slowly reveals to Jack the true about the life behind the walls, which he cannot understand. According to her plan, Jack is supposed to pretend being death and escape while his body is being taken off to the woods by Old Nick. The plan works out.

\subsection{Author Biography}

Emma Donoghue was born in Dublin, Ireland, as the youngest of eight children in 1969. Her father is the academic literary critic Denis Donoghue. She attended Catholic convent schools in Dublin and spent a year in New York at the age of ten. She studied English and French at the University College in Dublin and received her $\mathrm{PhD}$ in English from the 8 University of Cambridge, dealing with the concept of friendship between men and women in 18thcentury English fiction. She is a full-time writer since the age of 23.After commuting between Ireland, England and Canada, she finally settled in London, Ontario in Canada where she has been living since 1998 with her husband and their two children.

Donoghue is a writer of many genres, however she is known best for her contemporary and historical fiction. Her novels Stirfry, Hood and Landing Donoghue are all in some way connected with her hometown Dublin. Some other bestselling novels include Room, Slammerkin, The Sealed Letter or Life Mask.

\section{Method}

This study was descriptive qualitative research. It is a method of research which is aimed to get naturally understanding about particular phenomenon of human behavior or social setting and to describe the fact and characteristic of the object or subject systematically and accurately without seeking any relation among variables or relate among different elements (Sugiyono, 2010). The object of the study is Human understanding of the world experienced by Jack's character in the novel Room by Emma Donoghue (2010). After reading and getting the data 
the writer will classify the data which have relation to human understanding and perception in novel and will read some relevance support. Then Analyzing the data collected based on the theoretical frame work and Interpreting the data the results of this study by connecting them with the relevant theories and existing previous studies.

\section{Results \& Discussion}

The researcher presented the data that has been analyzed from the main character of Novel Room. The data categorized was based on John Locke theory about empiricism, Human understanding of perception the world. The table shows the categories of Jack's experience related to Human's understanding.

Table 1. Categories of Lead Character's Experiences related to Human Understanding

\begin{tabular}{|c|c|c|}
\hline No & Extract & $\begin{array}{c}\text { Human } \\
\text { Understanding } \\
\text { of Experience }\end{array}$ \\
\hline 1. & 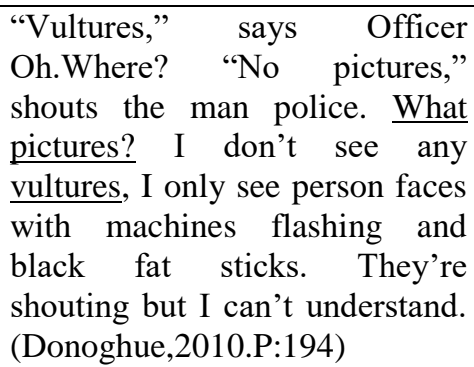 & $\begin{array}{l}\text { Sensory } \\
\text { experience }\end{array}$ \\
\hline 2. & $\begin{array}{l}\text { The floor's all shiny hard not } \\
\text { like Floor, the walls are blue and } \\
\text { more of them, it's too loud. } \\
\text { (Donoghue,2010.P:195. }\end{array}$ & $\begin{array}{l}\text { Sensory } \\
\text { experience }\end{array}$ \\
\hline 3. & $\begin{array}{l}\text { "And you, sir, I understand } \\
\text { you've been a remarkably } \\
\text { courageous young man." That's } \\
\text { me he's looking at. But he } \\
\text { doesn't know me and } \frac{\text { why he }}{\text { I'ma }} \\
\text { says } \\
\text { man?.(Donoghue,2010.P:195) }\end{array}$ & Inner experience \\
\hline 4. & $\begin{array}{l}\text { "Your son's been through a lot } \\
\text { tonight, perhaps he should wait } \\
\text { outside while we cover, ah . .." } \\
\text { But we're in Outside } \\
\text { already.(Donoghue,2010.P:196) }\end{array}$ & Inner experience \\
\hline
\end{tabular}

\begin{tabular}{|c|c|c|}
\hline 5. & $\begin{array}{l}\text { "We really have to go back to } \\
\text { Room," I tell her. "I need } \\
\text { Toilet." "That's OK, they've got } \\
\text { them } \\
\text { precinct.".(Donoghue,2010.P:19 }\end{array}$ & Inner experience \\
\hline 6. & $\begin{array}{l}\text { The car opens and a person with } \\
\text { no face looks in. Screaming. } \\
\text { "Jack, Jack," says Ma. "It's a } \\
\text { zombie." I keep my face on her } \\
\text { tummy. "Tm Dr. Clay, welcome } \\
\text { to the Cumberland," says the no } \\
\text { face with the deepest voice ever } \\
\text { booming. } \\
\text { (Donoghue,2010.P:199) }\end{array}$ & $\begin{array}{l}\text { Sensory } \\
\text { experience }\end{array}$ \\
\hline 7. & $\begin{array}{l}\text { We're driving along. When I see } \\
\text { a car coming I squeeze my eyes } \\
\text { every time. "They're on the } \\
\text { other side, you know," says Ma. } \\
\text { (Donoghue,2010.P:199) }\end{array}$ & $\begin{array}{l}\text { Sensory } \\
\text { experience }\end{array}$ \\
\hline 8. & $\begin{array}{l}\text { "Think of everything floating } \\
\text { around that your son's probably } \\
\text { never come in contact with } \\
\text { before." "OK." She puts one } \\
\text { mask on her and one on me with } \\
\text { loops around my ears. I don't } \\
\text { like the way it presses. "I don't } \\
\text { see anything floating around," I } \\
\text { whisper to Ma. "Germs," she } \\
\text { says. I thought they were only in } \\
\text { Room, I didn't know the world } \\
\text { was all full of them too. } \\
\text { (Donoghue,2010.P:199-200) }\end{array}$ & Inner experience \\
\hline 9. & $\begin{array}{l}\text { The a planet's changed to a } \\
\text { game of football with persons } \\
\text { with huge shoulders and } \\
\text { helmets. I wonder if it's really } \\
\text { happening for real or just } \\
\text { pictures.(Donoghue,2010.P:201) }\end{array}$ & $\begin{array}{l}\text { Sensory } \\
\text { experience }\end{array}$ \\
\hline 10. & $\begin{array}{l}\text { I climb up to her lap all crinkly. } \\
\text { "I saw us in TV" "So I heard. } \\
\text { How did we look?" "Small." } \\
\text { (Donoghue,2010.P:203) }\end{array}$ & $\begin{array}{l}\text { Sensory } \\
\text { experience }\end{array}$ \\
\hline 11 & $\begin{array}{l}\text { "Will we go explore?" } \\
\text { "Where?" "Outside." "We're in } \\
\text { Outside already." "Yeah, but } \\
\text { let's go out in the fresh air and } \\
\text { look for the cat," says } \\
\text { Ma.(Donoghue,2010.P:125) }\end{array}$ & $\begin{array}{l}\text { Inner experience, } \\
\text { it means Jack } \\
\text { have been out } \\
\text { from the room. }\end{array}$ \\
\hline
\end{tabular}




\begin{tabular}{|c|c|c|}
\hline 12. & $\begin{array}{l}\text { It's a different planet, it shows } \\
\text { more other cars like green and } \\
\text { white and a red one and a stony } \\
\text { place and there's things walking } \\
\text { that are persons. "They're tiny, } \\
\text { like fairies." "Nah, that's just } \\
\text { because they're far away," Ma } \\
\text { says. (Donoghue,2010.P:216) }\end{array}$ & $\begin{array}{l}\text { Inner experience, } \\
\text { Jack is gain the } \\
\text { story about } \\
\text { fairies with tiny } \\
\text { bodies. }\end{array}$ \\
\hline 13. & $\begin{array}{l}\text { We go in a huge bit that has all } \\
\text { tables, I never saw so many with } \\
\text { plates and glasses and knives } \\
\text { and one of them stabs me in the } \\
\text { tummy, one table I mean. The } \\
\text { glasses are invisible like ours } \\
\text { but the plates are blue, that's } \\
\text { disgusting. } \\
\text { (Donoghue,2010.P:217) }\end{array}$ & $\begin{array}{l}\text { Sensory } \\
\text { experience.cause } \\
\text { the room just has } \\
\text { some plates, } \\
\text { glasses and } \\
\text { knives. }\end{array}$ \\
\hline 14. & $\begin{array}{l}\text { It's like a TV planet that's all } \\
\text { about us, persons saying "Good } \\
\text { morning" and "Welcome to the } \\
\text { Cumberland" } \\
\text { "Congratulations," I don't know } \\
\text { for what. Some are in robes the } \\
\text { exact as ours and some in } \\
\text { pajamas and some in different } \\
\text { uniforms. Most are huge but } \\
\text { don't have long of hair like us, } \\
\text { move fast and they're suddenly } \\
\text { on all the sides, even behind. } \\
\text { They walk up close and have so } \\
\text { many teeth, they smell wrong. }\end{array}$ & $\begin{array}{lr}\text { Sensory } & \\
\text { experience, Jack } \\
\text { describe } \\
\text { around }\end{array}$ \\
\hline 15. & $\begin{array}{l}\text { "No kids," I whisper to Ma. } \\
\text { "What's that?" "Where are the } \\
\text { kids?" "I don't think there are } \\
\text { any." "You said there was } \\
\text { millions in Outside." "The } \\
\text { clinic's only a little piece of the } \\
\text { world," says Ma. "Drink your } \\
\text { juice. Hey, look, there's a boy } \\
\text { over } \\
\text { there."(Donoghue,2010.P:218) }\end{array}$ & $\begin{array}{l}\text { Inner experience. } \\
\text { When Jack was } \\
\text { room his ma tell } \\
\text { him about there } \\
\text { many child in } \\
\text { world and Jack } \\
\text { believe that. }\end{array}$ \\
\hline 16. & $\begin{array}{l}\text { I peek where she points, but he's } \\
\text { long like a man with nails in his } \\
\text { nose and his chin and his over- } \\
\text { eyes. Maybe he's a } \\
\text { robot?.(Donoghue,2010.P:220) }\end{array}$ & $\begin{array}{l}\text { Inner experience. } \\
\text { Jack has } \\
\text { knowledge about } \\
\text { robot gained } \\
\text { from the book } \\
\text { and watched TV }\end{array}$ \\
\hline 17. & $\begin{array}{l}\text { Ma says the plates aren't a } \\
\text { problem, the blue doesn't go on } \\
\text { the food, she gets me to rub it } \\
\text { with my finger to see. Also the } \\
\text { forks and knives, the metal feels } \\
\text { weird with no white 1handles } \\
\text { but it doesn't actually hurt. }\end{array}$ & $\begin{array}{l}\text { Sensory } \\
\text { experience }\end{array}$ \\
\hline
\end{tabular}

\begin{tabular}{|c|c|c|}
\hline & $\begin{array}{l}\text { There's a syrup that's to put on } \\
\text { the pancakes but I don't want } \\
\text { mine wet. I have a bit of all the } \\
\text { foods and everything are good } \\
\text { except the sauce on the } \\
\text { scrambled } \\
\text { (Donoghue,2010.P:221) }\end{array}$ & \\
\hline 18. & $\begin{array}{l}\text { "Yeah, but it has to go in the } \\
\text { trash because it's - it's like it's } \\
\text { dirty." I look at the food all } \\
\text { multicolored on the blue plates. } \\
\text { "It doesn't look dirty." } \\
\text { (Donoghue,2010.P:228) }\end{array}$ & $\begin{array}{l}\text { Sensory } \\
\text { experience }\end{array}$ \\
\hline 19. & $\begin{array}{l}\text { "There's sounds from - the } \\
\text { other rooms, I hear things and I } \\
\text { don't know if it's, where it is or } \\
\text { what." "It must all seem a bit } \\
\text { strange." Ma kind of laughs. } \\
\text { (Donoghue,2010.P:229) }\end{array}$ & $\begin{array}{l}\text { Sensory } \\
\text { experience }\end{array}$ \\
\hline 20. & $\begin{array}{l}\text { "Oh, Jack, you've been the } \\
\text { bravest little guy in the world, } \\
\text { you've brought my baby back." } \\
\text { What } \\
\text { baby?(Donoghue,2010.P:231) }\end{array}$ & Inner experience \\
\hline 21. & $\begin{array}{l}\text { Ma writes in a notebook Dr. } \\
\text { Clay gave her for homework. I } \\
\text { thought just kids going to school } \\
\text { do that, it means work for doing } \\
\text { at home but Ma says the Clinic's } \\
\text { not anybody's actual home, } \\
\text { everyone goes home in the } \\
\text { end.(Donoghue,2010.P:238) }\end{array}$ & Inner experience \\
\hline 22. & $\begin{array}{l}\text { We're in a corridor but not the } \\
\text { one on top of the stairs, the } \\
\text { Clinic has all different bits. I } \\
\text { don't think we went here before, } \\
\text { are we lost? } \\
\text { (Donoghue,2010.P:239) }\end{array}$ & Inner experience \\
\hline 23. & $\begin{array}{l}\text { In Outside the time's all mixed } \\
\text { up. Ma keeps saying, "Slow } \\
\text { down, Jack," and "Hang on," } \\
\text { and "Finish up now," and } \\
\text { "Hurry up, Jack," she says Jack } \\
\text { a lot so I'll know it's me she's } \\
\text { talking to not persons else. I can } \\
\text { hardly ever guess what time it } \\
\text { is, there's clocks but they have } \\
\text { pointy hands, I don't know the } \\
\text { secret and Watch isn't here with } \\
\text { her numbers so I have to ask Ma } \\
\text { and she gets tired of me asking. } \\
\text { (Donoghue,2010.P:244) }\end{array}$ & $\begin{array}{l}\text { Sensory } \\
\text { experience }\end{array}$ \\
\hline
\end{tabular}




\begin{tabular}{|c|c|c|}
\hline 24. & $\begin{array}{l}\text { I thought that meant a person } \\
\text { cleaner than everybody else, but } \\
\text { Ma says it's one who does the } \\
\text { cleaning. I think they're } \\
\text { invisible like elves. } \\
\text { (Donoghue,2010.P:237) }\end{array}$ & Inner experience \\
\hline 25. & $\begin{array}{l}\text { Noreen brings up lunch that's } \\
\text { soups and kebabs and a rice } \\
\text { that's not real called quinoa. For } \\
\text { after there's a salad of fruits and } \\
\text { I guess all them, apple and } \\
\text { orange and the ones I don't } \\
\text { know are pineapple and mango } \\
\text { and blueberry and kiwi and } \\
\text { watermelon, that's two right and } \\
\text { five wrong, that's minus three. } \\
\text { There's no banana. } \\
\text { (Donoghue,2010.P:243) }\end{array}$ & Inner experience \\
\hline 26. & $\begin{array}{l}\text { "The very best thing you did } \\
\text { was, you got him out early," } \\
\text { says Dr. Clay. "At five, they're } \\
\text { still plastic." But I'm not plastic, } \\
\text { I'm a real boy. } \\
\text { (Donoghue,2010.P:260) }\end{array}$ & Inner experience \\
\hline 27. & $\begin{array}{l}\text { She says these ones were Ma's } \\
\text { and my Uncle Paul's when they } \\
\text { were kids, I don't think she's } \\
\text { lying but it's hard for it to be } \\
\text { true that Ma was ever a kid. } \\
\text { (Donoghue,2010.P:246) }\end{array}$ & Inner experience \\
\hline 28. & $\begin{array}{l}\text { "Well, the DA tells me she's } \\
\text { hoping } \\
\text { for twenty-five to life, and for } \\
\text { federal offenses there's no } \\
\text { parole," says Morris. "We've } \\
\text { got kidnapping for sexual } \\
\text { purposes, false imprisonment, } \\
\text { multiple counts of rape, criminal } \\
\text { battery ...." He's counting on } \\
\text { his fingers not in his head. } \\
\text { (Donoghue,2010.P:252) }\end{array}$ & $\begin{array}{l}\text { Sensory } \\
\text { experience }\end{array}$ \\
\hline 29. & $\begin{array}{l}\text { Ma lets me revolve in the door } \\
\text { five } \\
\text { times. She pushes and we're out. } \\
\text { It's so bright, I think I'm going } \\
\text { to scream Then my shades get } \\
\text { darker and I can't see. The air } \\
\text { smells weird in my sore nose } \\
\text { and my neck's all } \\
\text { tight.(Donoghue,2010.P:262) }\end{array}$ & $\begin{array}{l}\text { Sensory } \\
\text { experience }\end{array}$ \\
\hline
\end{tabular}

\begin{tabular}{|l|l|}
\hline 30. & $\begin{array}{l}\text { she's taking the paper out of my } \\
\text { hand. "What about your Peter } \\
\text { Rabbit book?" "But that's me, } \\
\text { the Bonsai Boy." "The bouncy } \\
\text { what?" She looks at the paper } \\
\text { again and pushes her hair out of } \\
\text { her face, she sort of groans. } \\
\text { "What's bonsai?" "A very tiny } \\
\text { tree. People keep them in pots } \\
\text { indoors and cut them every day } \\
\text { so Inner sensory } \\
\text { they stay all curled up." I'm } \\
\text { thinking about Plant. We never } \\
\text { cutted her, we let her grow all }\end{array}$ \\
$\begin{array}{l}\text { she liked but she died instead. } \\
\text { "I'm not a tree, I'm a boy." } \\
\text { (Donoghue,2010.P:270) }\end{array}$ \\
\hline
\end{tabular}

The table above is made to answer the question of the research which is about Jack's previous life experience influence his understanding of his perceived world. From the table we can see two of human understanding influence to Jack, sensory and inner experience. That extract have 38 (thirty eight) extract from Sensory experience has 19 (nineteen) extracts and inner experience has 19 (nineteen) extracts. From this data the authors compare the extract in accordance with the categories of sensory experience and inner experience based on their understanding.

\subsection{Sensory Experience (Sensation)}

In the process of perception is influenced by stages known as natural processes or physical processes, is the process of capturing a stimulus by human sensory devices. As stated in the theory that human beings gain knowledge through sensory experience. Human senses are divided into five: vision, smell, hearing, taste and touch. Locke said that all concepts or ideas that express human knowledge actually originate from human experience and that experience is obtained from the senses or reflection on what the senses provide. Locke distinguishes between two kinds of ideas namely, simple ideas and complex ideas. Simple ideas are ideas that are captured through the five senses (smell, sight, palpation, etc.).In this novel, researchers found that the main characters in novel gain knowledge through the sense of sight, hearing and touch that influence perception as shown in extract below.

\section{Extract 1:}

"Vultures," say officer Oh. Where?"No Pictures," shouts the man police. What pictures?I don't see any vultures, I only see person faces with machines flashing and black fat sticks. They're shouting but I can't understanding". (Donoghue,2010.P:194)

The extract above shows Jack's sensory experience and perception of what he has received from his senses. As 
received from the sensory of hearing and vision. As of the extract 1 , above is that Jack thinks the reporter is vulture. Jack is looking for a vulture that was used by the police but does not see it. Jack only sees the reporters with a camera in their hand. Vulture that the police mean is a curse. In the next phrase the police said "no picture" spontaneously Jack said "what picture?" and again Jack does not see the "picture" what the police means. The picture that was filed by the police is do not take pictures which means do not take photo. The experience from the sense he got while in the room whose only saw a picture made by $\mathrm{Ma}$ and himself, the vultures that Jack was driving were bird that had died and become dead. And Jack uses Human understanding of knowledge through experience by sensory experience and in another case it happened with sensory experience:

\section{Extract 9:}

The planet's changed to a game of football with persons with huge shoulders and helmets. I wander if it's really happening for real or just pictures. (Donoghue,2010.P:201)

To appraise the world, Jack is observing and giving attention around him, because everyone has different perception with a thing, it is why influence his perception. This perception shows all Jack's attention in assessing things is outside. This case show how attention is directed. Jack is in the waiting room and giving his attention to what is around him and thinks about everything in his head. Jack's perception is shown in the phrase "I wander if it's really happening for real or just pictures" when he saw a football player wearing a helmet and has broad shoulders. Attention shown by Jack is when Jack looks at the football player, as explained before that observing and giving attention around him, because everyone has different perception with a thing. Just like when Jack was in seven rooms Jack gave his attention out of the window and made him see the entire city. Jack's sensory experience as factors influence his perception of the world.

\section{Extract 10}

I climb up to her lap all crinkly. "I saw us in TV", "So I heard, How did we look?” "Small.(Donoghue,2010.P: 203)

For the first time Jack shows himself and his Ma on the TV and described himself is small. What shows Jack's perception is when he answers "small". What Jack meant was they looked as small on TV as Dora had seen on TV while in the room. What affects Jack's perception is the Jack's knowledge he gets while in the room is when Jack is watching TV and has never seen himself on TV.

\section{Extract 2:}

The floor's all shiny hard not like Floor, the walls are blue and more of them, it's too loud. (Donoghue,2010.P:195)

\section{Extract 19}

"there's sounds from - the other rooms, I hear things and I don't know if it's, where it is or what." "it must all seem a bit strange." $\quad M a$ kind of laughs.(Donoghue,2010.P:229)

From extracts $2 \& 19$ Jack getting a noise he don't know. It simultaneously that makes him not know what to hear first. Jack feels like annoying sounds, in room was so quite then when he is outside, the world is noise place. The room he had yesterday was sound proof, so no sound could penetrate the cork on the wall.This proves that the sensory experience experienced by Jack when he came out of his room for five years affected his perception of the world. Jack whose outside felt confused what he had to hear first.

The sense power connects humans with concretematerial things. The senses knowledge is partial, because of the differences between the senses with one another. Sensory knowledge varies according to differences in the senses and the limitations of the sense organs and their experiences. The extract of sensory experience can be found in Datum; 13, 14, 17, 18, 23, 28, 29, 31, 33, 35, 36 and 38 .

\subsection{Inner Experience (Reflection)}

Understanding the human's inner experience thoughts, feelings, and sensations expressed by purposeful words, impulsive utterances, and creative metaphors isthe goal of psychology at its inceptions (Jabber \& Al-Saedi, 2020). This study examined the phenomena of inner experience and discovered that inner speech, inner seeing, symbolized, thinking, feelings, and sensory awareness each occurred in approximately one quarter of sampled moments. In this novel, researchers found that the main characters in novel gain knowledge through the inner experience shown in extract.

\section{Extract 3:}

"and you, sir, I understand you've been a remarkably courageous young man." That's me he's looking at. But he doesn't know me and why he says I'm man?.(Donoghue,2010.P:195)

Jack is amazed because he is called a man. Jack perceives men as men who are big and tall adults. A man who has worked like Dr. Clay, Old Nick and uncle Paul. With the age of five Jack felt he was still a boy and not a man. Being the man like a young man, this is a compliment that Jack accepts.

\section{Extract 4:}

"your son's been through a lot tonight, perhaps he should wait outside while we cover, ah.." but we're in outside already. (Donoghue,2010.P.196)

Not being in the room made Jack outside, even Jack was outside and someone told him to get out. Other than that the perception that shows Jack's experience from the room to the outside occurs when Jack feels should really have to 
be in the room because he needs a toilet and the toilet was only in the rooms.

\section{Extract 5:}

"we really have to go back to Room," I tell her. "I need Toilet." "that's OK, they've got them here in precinct." The Captain shows us the way past the amazing machine and I touch the glass nearly at the chocolate bars. (Donoghue,2010.P:197)

Jack's experience is not just about the toilet in the room. Some beaver reminds Jack about room an makes all the outdoor stuff strange.Because while outside Jack does not see the toilet and the toilet in the room is the only toilet that Jack knows.

\section{Extract 12:}

It's a different planet, it shows more others cars like green and white and a red one and a stony place and there's things walking that are person. "they're tiny, like fairies," "nah, that's just because they're far away," Ma says. (Donoghue,2010.P:216)

Jack tried to simplify what was on his mind but he knew that what he was seeing is a human. The perception shown by Jack is "they're tiny, like fairies," the factor that affects Jack's perception is his knowledge of the little human who is always in the room is a fairy. Jack is facing out the window and looks at people from a distance which makes them look small. That's why Jack perceives the person he sees from jah as a fairy. The attention factor that Jack is showing is when he is paying attention to what experience is affecting Jack's perception.

\section{Extract 15 :}

"No Kids," I whisper to Ma. "What's that" "Where are the Kids?" "I don't think there are any." "you said there was millions in outside." "the clinic's only a little piece of the world," says Ma. "Drink your juice. Hey, look, there's a boy over there." (Donoghue,2010.P:219)

The same case Jack's uses the inner experience from another situation and try it to utterance his perception. What shows Jack's perception is "I don't think there are any" "You said there was millions in outside" Ma told Jack that many children his age, and Jack believed. After being outside Jack only found a few children while outside, especially in the clinic. Jack who thinks there will be many kids who will gather in one place. What affects Jack's perception is that while in the room a lot means they are in one place and gathering.

Other than that case, Jack thinks Ma do the homework Ma made the note requested by Dr. Clay, to make it easier for her to remember all happen that were in the room. He do not think if homework can finish in clinic not in home. Other factors that influence Jack's perceptions are experience and memory factors, while Jack thinks about everything in the room as home and influence his perception of the word. The extract of sensory experience can be found in Datum; 8, 11, 22, 24, 25, 26, 27, 30, 32, 34, and 37.

This study does not compare between sensory and inner experience, this study only shows the data that is included in the sensory section because it uses five sense and inner to show some of its parts. Between the sensory and the inner experience, they connected with each other, the experience gained from the eyes will be remembered by the inner experience, the smelled by the nose will be remembered by the inner experience. From sensory and inner experience, they produce knowledge and knowledge influence their perception. Every person has a different experience from their respective sensory and their experience, this is also one of the factors affecting perception.

Everyone has their own views on something to judge. They are right with what they know and we are not wrong with what we know.

\section{Conclusion}

Tabula rasa is closely related to experience, and with this John Locke does not recognize the existence of intuition that builds human understanding. Everything a child knows is only the result of what his parents teach him. Human understanding or tabula rasa theory from John Locke said that humans are born like white paper in which all children born do not have any knowledge, they get knowledge through sensory experiences and inner experiences during their lives. The knowledge acquired is processed by sensory sensations of smell, hear, touch, the sense of taste and is influenced by stimuli, as well as the inner experience their inner experience of trust, desire and memory. Because a baby has different experiences both from sight, smell, hear, touch and taste as well as inner experiences such a beliefs, desires and memories so that the resulting perceptions are also different. Likewise, it was experienced by Jack, who for the first 5 (five) years of his life lived with Ma in a Room, did not know the world, had never socialized with anyone other than Ma. Thus affecting his perception of the world, so when Jack faced the world for the first time Jack felt something strange with what was seen, touched, heard, smelled and felt. $\mathrm{He}$ is inner experience influenced when Jack remembers everything in the room and compares it with what he remembers, as well as his beliefs and desires. All of Jack's knowledge is very limited, so it is not uncommon for Jack to perceive things strangely and sometimes to Jack's surprise. Perception according to Rakhmat (2005) says that experiences about objects, events, or relationships are obtained by concluding information and interpreting messages. Jack underwent a process of interpretation through sensory experiences and inner experiences which he received while in the room for 5 (five) years. Likewise, the knowledge gained from sensory and inner experience can affect one's perception. 


\section{References}

Bimo, W. (2003). psikologi social (suatu pengantar). andi offset.

Brown, M. (March 16, 2011). Orange prize longlist tackles difficult subjects - and alligators. The Guardian. https://www.theguardian.com/books/2011/mar/16/or ange-prize-longlistfiction?INTCMP=ILCNETTXT3487/

Frenette, B. (September 29, 2010). Finalists announced for the Writers Trust Awards. National Post. http://arts.nationalpost.com/2010/09/29/finalistsannounced-for-the-writers-trust-awards/

Hadiwijono, H. (2007). Seri Sejarah Filsafat. Mizan Pustaha

Ibrahim. (2017). The development of human understanding of the World in PK movie by Rajkumar Hirani. Universitas Alauddin Makasssar.

Jabber, K. W., \& Al-Saedi, H. T. J. (2020). A Study of Hot and Cold Metaphors in Iraqi Arabic. REiLA : Journal of Research and Innovation in Language, 2(2), 46-58. https://doi.org/10.31849/reila.v2i2.4227

Locke, J. (1664) Essays on the Law of Nature, ed. and trans. W. von Leyden, Oxford: Oxford University Press, 1954; ed. and trans. R. Horwitz, J. Strauss Clay and D. Clay as Questions concerning the Law of Nature, Ithaca, Cornell University Press, 1990.

Nugroho, A. R. (2017). Ma's trauma: phsycoanalytic study on EmaDonongue's novel Room (2010).

Nurhayati, E., \& Thoyibi, M. (2017). Child Perspective Of The World Reflected In Emma Donoghue's Room (2010) Novel: A Sociological Approach (Doctoral dissertation, Universitas Muhammadiyah Surakarta). Nursafira, M. S., Putri, W. C., Yunira, S., Gari, N., \& Hamuddin, B. (2019). Psychological Analysis of Fatih's Character-Building in Egosentris: A Novel by Syahid Muhammad. Elsya : Journal of English Language Studies, 1(1), 1-10. https://doi.org/10.31849/elsya.v1i1.2461

Shihab, M. Q. (2002). Tafsir al-misbah. Jakarta: lentera hati, 2.

Rahman, F. (2017). The revival of local fairy tales for children education. Theory and Practice in Language Studies, 7(5), 336-344.

Rakhmat, J. (2005).. Psikologi Komunikasi. PT. Remaja Rosdakarya.

Sugiyono. (2010). Metode penelitian pendidikan pendekatan kualitaif,dan $R \& D$. Alfabeta.

Tafsir, A. (2008). Filsafat umum, akal dan hati sejak Thales sampai Capra. Rosda. 